\title{
Analysis of Pre and Post Merger and Acquisition Financial Performance of Banks in Pakistan
}

\author{
${ }^{1}$ Qamar Abbas, ${ }^{2,3}$ Ahmed Imran Hunjra, ${ }^{1}$ Rashid Saeed, ${ }^{4}$ Ehsan-Ul-Hassan, ${ }^{2}$ Muhammad Shahzad Ijaz \\ ${ }^{1}$ Bahauddin Zakariya University Multan, Pakistan \\ 2UIMS, PMAS-Arid Agriculture University Rawalpindi, Pakistan \\ ${ }^{3}$ Iqra University Islamabad, Pakistan \\ ${ }^{4}$ Sukkur Institute of Business Administration, Sukkur, Pakistan \\ *qamarabbas1060@gmail.com
}

\begin{abstract}
Merger and Acquisition is a strategy adopted by the organizations globally to meet the needs of dynamic business environment. This strategy also has much importance in Pakistan mostly in banking sector. Therefore, the objective of the study is to assess the impact of M\&A on the financial performance of banks in Pakistan. The accounting and financial data of 10 banks were used in this study. Data was taken from the financial statement analysis (FSA) by State Bank of Pakistan from the period of 20062011. For the analysis of pre and post Merger and Acquisition performance 15 financial ratios were used in the study. To compare the results Paired sample t-Test was used to measure the significant difference between pre and post M\&A financial performance. The overall results show that there is no significant difference in financial performance. It is concluded that there is insignificant difference between pre and post M\&A performance of banks in Pakistan.
\end{abstract}

Keywords: Merger and Acquisition, Banking Sector of Pakistan, Financial Performance, Profitability Ratio, Liquidity Ratio, Leverage Ratio

\section{Introduction}

The Business environment is going to be fast day-by-day because of dynamic changes in the global environment. The main factor, which affects the organizations' performances, that is increasing competition. The most effective and well-known approach organizations use to compete in such a fast business environment is Merger \& Acquisition (M\&A). There is a small difference in both terms Merger and Acquisition although they use conversely. If two organizations agree to move forward as a single or joint new entity for their mutual benefits then the merger occurs, while acquisition occurs when an organization takes over some assets, equipment, plant business unit of another organization (Sherman, 2011). Organizations have to realize the advantages to go into Merger and Acquisition and to identify the target business (Zahid \& Shah, 2011). Worldwide scenario of Merger and Acquisition is represented in figure 1. In 2007, there was a high watermark of M\&A deals worldwide when total number of deals of M\&A reached nearly 50,000 worldwide. There was a low point in 2009 during the great recession when the total deals of M\&A decreased by 42,000 . It is clear from the figure that the number of $M \& A$ transactions have increased fourteen times over the last twenty-five years; 3,000 to 42,000 transactions from 1985 to 2011. The length of increased number of transactions as well as the transactions value has moved from $\$ 500$ Billion to $\$ 6,000$ Billion; which is a twelve times increase (IMAA, 2011). The trend in the figure shows that the International Merger and Acquisition goes toward the developing countries and from the developing counties, means in both ways that is ultimately modernizing the world's economic boundaries (Chapman, 2003). Merger and Acquisition clutch in time and through this strategy organization performs well (Martynova et al., 2006 and Kropf \& Viswanathan, 2004).

Merger and Acquisition and the performance of Financial Sector: Financial sector has been experiencing an amazing consolidation and restructuring procedure worldwide. The exclusion of the restrictions imposed regarding Merger and Acquisition in U.S. has given a rise to a wave of Mergers and Acquisitions. However, there are few factors, which are acting as a hurdle in the consolidation of financial services. An identical consolidation process of the banking industry is also being spotted in Europe and the number of banks Mergers and Acquisitions has increased in European countries. The firms are consolidating since 1989 by anticipating in holding the global financial system and probable to face 
further re-structuring against the consequences of the recent crisis in financial markets. Such firms are expected to hold the global financial system (Berger \& DeYoung, 2001).

Merger \& Acquisition and Financial performance in Pakistan: Based on historical information the accessible data on Karachi Stock Exchange (KSE) and shows that from the period of 1995-2011 the total mergers appeared are 121. According to Competition Commission of Pakistan (CCP), from the period of 2007-2011, the number of mergers was 48 and the number of acquisitions was 208. Due to the increasing competition in business environment according to the technological advancement, State Bank of Pakistan (SBP) is aiming to further consolidation in the banking sector by the most effective way that is the encouragement of Merger and Acquisition. The rise in the competition, value creation, and the changes made in the regulations for increasing product portfolio entering new markets are the reasons that's why the Mergers and Acquisitions has become preferred strategic tool for maintaining strong performance. The financial sector of Pakistan is main sector that is involved in Merger and Acquisition. The current down size in the economy of Pakistan, the failure of other business conditions and the global financial crises play a big roll to force the organizations to come in Merger and Acquisition deals in financial sector of Pakistan. Furthermore, most of the studies signify research in Pakistan for the analysis of same event but they leave some gaps and advise some future direction for the further analysis. Therefore, there is a need to research further on the scenario like M\&A in Pakistan in banking sector, where many deals occurred in the different times. This study is drawn on the banking sector of Pakistan. It is beneficial for the further research in banking sector of Pakistan.

Figure 1: A clearer picture of Merger and Acquisition worldwide, (1985 to 2011)

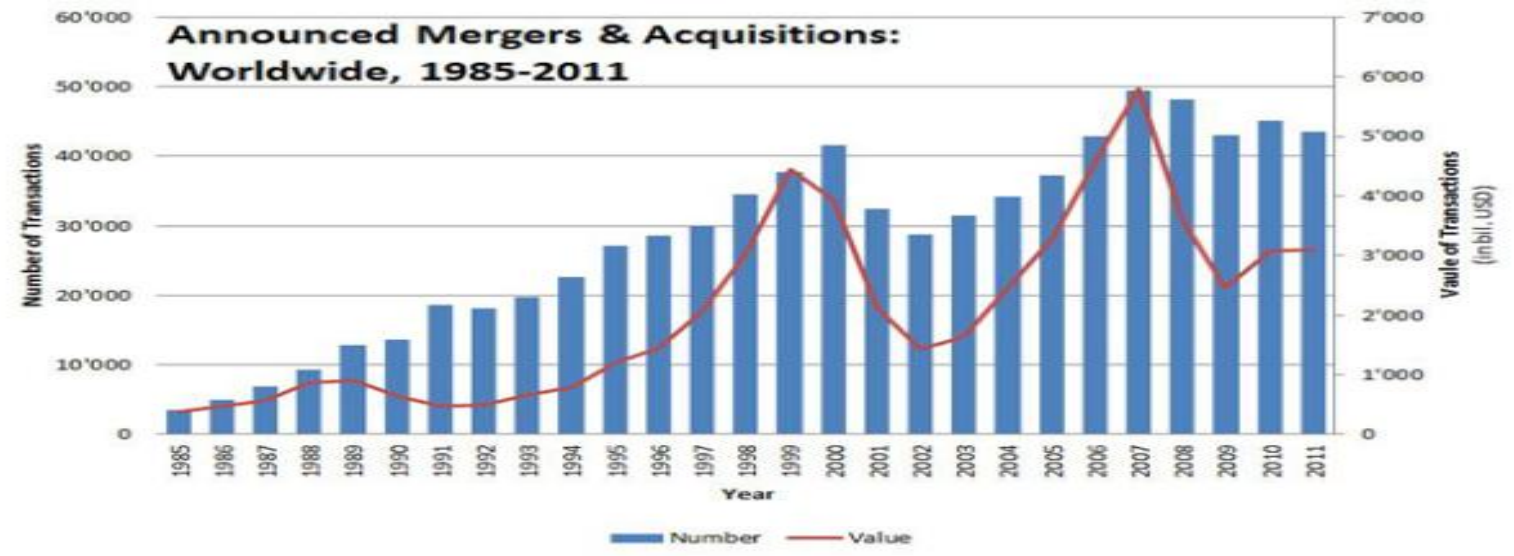

Source: Thomson Financial, Institute of Mergers, Acquisitions, and Alliances Analysis

Generally, there are more than hundreds of studies identifying the pros and cons of Merger and Acquisition regarding firm's performance in different sectors. Similarly, the researches on banking sectors also have much importance for all financial and non-financial sectors. Specifically the research on banking sector regarding the impacts of Merger and Acquisition has much importance for concerned customers, competitors, future growth, recent management, shareholders etc. This research is more helpful for the relevant field to get future direction and to be aware about the clear scene of competitive and technological global market. This study also proves that Merger and Acquisition is an imperative area for future research so it is more helpful for the researchers to further research in the future. To evaluate the financial performance of organizations the financial indicators are used like; profitability \& efficiency, liquidity and leverage ratios which may be affected by M\&A. When companies are merged or acquired, there are more chances that their performance is affected. Therefore, the objective of this study is to assess impact of M\&A on the financial performance of banks in Pakistan. According to the previous studies merger and acquisition has many impacts on firm's performances of organizations.

\section{Literature Review}

Merger and Acquisition is not limited phenomena it has been extended through all over the world. Nowadays it has become the requirement of organizations that want to compete in the recent dynamic business environment. This part of study represents to analyze the impact of M\&A on the firm's performance. It is found that some countries like India, China, and Brazil are more engaging in Merger 
and Acquisition contracts. These M\&A deals enhanced the performance of business (Zahid \& Shah, 2011). Mantravadi \& Reddy (2008) found the relationship between the type of industry and the result of Merger deals. They used three years post and three years pre merger values for calculating the financial ratios. They concluded that industry look to have impacts on post-merger operating performance. Ismail et al. (2011) studied Turkish organization Merger and Acquisition and they found a mix of Merger and Acquisition performance improvement. Tambi (2005) found the impact of Merger and Acquisition on the firm's performance. Performance of the organizations was calculated by three factors which are: Profit after Tax, Return on capital employee and Profit before Interest Tax Depreciation and Amortization. Results of the study showed that Merger and Acquisition had been unsuccessful. Efficiency and profitability examine the development of operating performance of merged companies' for pre and post merger based on accounting data (Gjirja, 2001).

Sinha and Gupta (2011) studied M\&A during the period of 1993 - 2010 in the financial sector of India. This study was specially based on assessment of Merger and Acquisition with respect to accounting measures. The study results proved that profit after tax (PAT) and profit before depreciation, interest, tax and amortization (PBDITA) were enhanced, but the liquidity of firm's was reduced. In both pre \& post, M\&A situation the interest coverage found to be a main factor of return on shareholders' equity (ROE). Similarly, the profit margin found to be equally vital. Calomiris and Karenski (1996) and Caprion (1999) provided evidences that Merger and Acquisition influence the efficiency of most banks positively. While on other hand in another study results were quiet surprising, showed performance is not positively influenced by mergers and acquisitions operations in United States banking industry in terms of efficiency (Amel et al., 2004 \& Berger et al. 1999). The results of all these studies did not give a clearer picture regarding the relationship between these variables (Merger \& Acquisition, and performance) except providing mixed evidence. Summing up these studies, most of them examined the impact of Merger and Acquisition's operations on cost efficiency, using simple accounting cost ratios and the impact of these operations on cost efficiency (Berger \& De-Young, 1997). In addition, some evidences are in support with the achievement of efficiency gain and cost saving in sparse (Kwan and Elsenbeis, 1999).

Badreldin and Kalhoefer (2009) calculated that companies return on equity in order to the level of success and progress of banking reforms in consolidating and strengthening the banking sector. An increase in performance was examined when these companies were compared with pre-merger performance. Mishra and Chandra (2010) examined Indian pharmaceutical firms' performance with respect to Merger and Acquisition. They found that Merger and Acquisition is not effective in influencing the profitability of the firm in long run. Amel et al. (2004) concluded by the synthesis of literature that the synergies and efficiencies are achieved in most cases because of Mergers in the major industrial countries. It was examined that Mergers and Acquisitions can play any role to solve bank problems. Cornett et al. (2006) conducted a study to evaluate the operating performance of commercial bank mergers. They found that after the mergers industry-adjusted operating performance of merged banks increases appreciably. Pankaj and Sushant (2011) did Pre and post analysis of firms and concluded a positive effect on the profitability of firms, but in most of the cases liquidity was declined. After reviewing the literature about the impact of Merger and Acquisition on the firm's performances it s found that there is relationship between Merger and Acquisition and the performance of organizations. It is reviewed form various studies that Merger and Acquisition has not the same impact on the performance of all merged firms' in all over the World. The literature concludes the findings of different studies, which were conducted in different countries through all over the world in different types of industries. Table 1 is showing the compilation of 25 recent authors' findings in the area of M\&A from the period of 2006-2012

Table 1: Compilation of 25 recent studies results by using different ratios for the period of 20062012.

\begin{tabular}{llllll}
\hline & Profitability & Efficiency & Liquidity & $\begin{array}{l}\text { Financial } \\
\text { Leverage }\end{array}$ & $\begin{array}{l}\text { Overall Financial } \\
\text { Performance }\end{array}$ \\
\hline Increased & $62 \%$ & $50 \%$ & $10 \%$ & $0 \%$ & $48 \%$ \\
$\begin{array}{l}\text { Decreased } \\
\text { Average }\end{array}$ & $31 \%$ & $50 \%$ & $80 \%$ & $0 \%$ & $32 \%$ \\
$\begin{array}{l}\text { Results/Insignificant } \\
\text { Total }\end{array}$ & $8 \%$ & $0 \%$ & $10 \%$ & $100 \%$ & $20 \%$ \\
\hline
\end{tabular}


This table shows the percentage results of financial indicators found from previous studies. This compilation indicates that out of 25 studies $62 \%$ studies increased, $31 \%$ decreased and $8 \%$ studies showed average results in their profitability after M\&A. Similarly, the percentage in efficiency, leverage, liquidity, and overall financial performance is examined.

Hypotheses Statements: It is reviewed from the vast literature that Merger and Acquisition has positive as well as negative impact on the performance of organizations. This study is conducted on the banking sector of Pakistan to evaluate the impact of Merger and Acquisition on the financial performance. Therefore, following are the assumptions towards the hypothesis statements of the study:

HOa: There is no significant difference in the Profitability ratios between pre and post M\&A.

H1a: There is a significant difference in the Profitability ratios between pre and post M\&A.

HOb: There is no significant difference in the efficiency ratios between pre and post M\&A.

$H 1 b$ : There is a significant difference in the efficiency ratios between pre and post M\&A

HOc: There is no significant difference in the liquidity ratios between pre and post M\&A.

H1c: There is a significant difference in the liquidity ratios between pre and post M\&A

HOd: There is no significant difference in the leverage ratios between pre and post M\&A.

H1d: There is a significant difference in the leverage ratios between pre and post M\&A.

HOe: There is no significant difference in the overall financial performance of banks in Pakistan between pre and post $M \& A$.

H1e: There is a significant difference in the overall financial performance of banks in Pakistan between pre and post $M \& A$.

\section{Methodology}

Various approaches and techniques have been reviewed from previous researches which were conducted to evaluate the impact of Merger and Acquisition on the performance of organizations. This study is hypothetical in nature and it is based on a quantitative analysis between pre and post M\&A period hence it is a secondary based research. Various statistical techniques are reviewed from the previous studies. Ravichandran et al. (2010) studied to assess the performance and efficiency of some public and private banks that faced Merger. He used the ratio analysis and drawn t-Test for the evaluation of his study. Okpanachi (2007) studied for a comparative analysis to assess the impacts of M\&A in Nigeria on the financial efficiency of banks. He used t-test in SPSS to analyze the performance at significant level of 5\% for this secondary research. Kouser and Saba (2011) evaluated the impact of combination of business on their financial performance in the financial sector of Pakistan through financial ratios using financial and accounting data. They used paired $t$-test for the analysis of data.

Ong et al. (2011) studied to analyze the financial performance for Malaysian banking sector using pre and post merger accounting and financial data. They employed three methods to analyze pre and post merger performance; first they used comparison and ratio analysis. Second, they analyzed performance using paired sample t-test for pre and post merger performance and third, DEA approach was used to measure the bank's efficiency. In this study the methodological techniques of Ong et al, (2011) have been followed; two relative techniques have been chosen for this study. First a comparison of ratio analysis is used for pre and posts M\&A, where t-Test is used to measure the significant difference for pre and post M\&A performance. Second paired sample t-test is used to check the significance difference in financial performance between pre and post M\&A.

Table 2: List of the Merged and Acquired Banks

\begin{tabular}{lllll}
\hline S. No & Type of Deal & Date of Deal & Acquirer/Bidder Banks & $\begin{array}{l}\text { Acquired/Merged/Target } \\
\text { Organizations }\end{array}$ \\
\hline 1 & Merger & $1 / 1 / 2008$ & NIB Bank Limited & PICIC Commercial Bank Limited \\
2 & Acquisition & $25 / 06 / 2008$ & Standard Chartered & $\begin{array}{l}\text { American Express Bank Limited } \\
\text { in Pakistan }\end{array}$ \\
& & & Bank Limited. & Saif Power Limited \\
3 & Acquisition & $15 / 09 / 2008$ & Habib Bank Limited. & Bank Islami Pakistan Limited \\
4 & Acquisition & $28 / 10 / 2008$ & Dubai Banking Group LLC. & $\begin{array}{l}\text { KASB Bank Limited } \\
5\end{array}$ \\
Merger & $7 / 11 / 2008$ & Atlas Bank Limited & and KASB Capital & Network Leasing Corporation \\
\hline
\end{tabular}




\begin{tabular}{lllll}
\hline 7 & Merger & $30 / 01 / 2009$ & $\begin{array}{l}\text { HSBC Bank Middle } \\
\text { East Limited. }\end{array}$ & $\begin{array}{l}\text { Limited } \\
\text { Amalgamation of the Hong Kong } \\
\text { and Shanghai Banking Corporation } \\
\text { (all branches in Pakistan ) }\end{array}$ \\
$\begin{array}{llll}\text { Habib Sugar Mills Limited by M/s. } \\
\text { Royal Bank of Scotland }\end{array}$ \\
9 & Acquisition & $\begin{array}{l}\text { Acquisition } \\
10\end{array}$ & $\begin{array}{l}\text { Merger } \\
\text { Askari Leasing Limited }\end{array}$ \\
\hline
\end{tabular}

Data \& Sample of the study: The information about Merger and Acquisition deals in Pakistan was available on the site of KSE and CCP from 2002 to 2011 (Table 1, Appendix 1). There were total 57 deals of M\&A in banking sector of Pakistan, out of which 19 were Acquisition and 38 were Merger deals. The M\&A were occurred during the period of 2008-2009 are selected to measure the financial performance. There were only 16 deals of M\&A in the selected period. Due to the unavailability of data on 10 banks were chosen for the period of 2006-2011. It is shown in table 2 that out of ten M\&A deals, 5 are Merger and $\mathrm{r} 5$ are Acquisition deals. The data is collected from the financial statements from SBP for the perspective banks.

Statistics \& Techniques: To measure the financial performance, Profitability \& Efficiency, Liquidity and leverage ratio(s) were used as financial indicators. These indicators are measured through financial ratios, which are given in table 3 .

Table 3: Proxies to Measure the Financial Performance

\begin{tabular}{|c|c|c|}
\hline Variables & Ratio(s)/Indicators & \\
\hline \multirow{8}{*}{$\begin{array}{l}\text { Profitability \& } \\
\text { Efficiency }\end{array}$} & Return on Equity (ROE) & $=$ Net profit after tax / Total equity \\
\hline & Return on Assets (ROA) & $=$ Net profit after tax $/$ Total Assets \\
\hline & $\begin{array}{l}\text { Net Interest Margin } \\
\text { Assets }\end{array}$ & $=$ Interest earned- interest expense $/$ Total \\
\hline & Earnings Per Share (EPS) & $=$ Net profit after tax / No. of ordinary shares \\
\hline & Spread Ratio & $=$ Net interest income $/$ Total interest earned \\
\hline & Interest expense to Interest Income & $=$ Interest expense $/$ Interest Income \\
\hline & Non Interest Income to Total Assets & $=$ Non Interest Income $/$ Total Assets \\
\hline & Non Interest Expense to total Income & = Non Interest Expense / Total Income \\
\hline \multirow[t]{4}{*}{ Liquidity } & Cash \& Cash equivalent to total assets & $=$ Cash\& Cash equivalent $/$ Total assets \\
\hline & Investment to total assets & $=$ Investment $/$ Total assets \\
\hline & Advance net of provision to total assets & ts = Advance net of provision / Total assets \\
\hline & Total Liabilities to total assets & $=$ Total Liabilities $/$ Total assets \\
\hline \multirow[t]{3}{*}{ Leverage } & Debt to Equity Ratio & $=$ Total Debt $/$ Total Equity \\
\hline & Total Deposit to total Equity & $=$ Total Deposit / Total Equity \\
\hline & Capital Ratio & =Total Equity / Total Assets \\
\hline
\end{tabular}

The analysis is done about all selected ratios using pre and post M\&A data for the banking sector in Pakistan. All the ratios are calculated taking the average of two years before M\&A and two years after the M\&A of banks. Yener \& David (2004) suggested that two years pre and post M\&A data is sufficient. They also argued that there might be negative effect of longer time due to some other external economic factors. To materialize the benefits of M\&A two years are enough (Achtmeyer's, 1994). To Measure the financial performance of banks accounting and financial data of selected banks from the period of 20062011 are used in this study. Two techniques are applied in this study to analyze the pre and post M\&A financial ratios. First T-test (Paired two sample for means) is employed to check the significant difference between pre and post M\&A financial ratios individually for each ratio. Then to check the significant difference of overall financial performance between pre and post of M\&A a paired sample t-test is employed using Statistical Package for the Social Sciences (SPSS). 


\section{Results and Discussion}

All the findings and results of the study are discussed here. Hypotheses of the study have been tested using t-test to check the significant difference for each ratio and paired sample t-Test also used to analyze the statistical significant difference for overall Pre and Post M\&A financial performance. The results and discussion of this study are compared with some previous studies, which were conducted on the same topic.

T-Test: Paired Two Sample for Means: Taking average of pre and post M\&A performance t-Test measure the significant difference at 5\% significant level between pre and post M\&A of each ratio collectively for all the banks which are taken as a sample for the study. For each pre and post M\&A financial ratio P-value (two-tail) is taken to check the significant impact. Below in the fourth column of table $4 \mathrm{P}$-value is shown for each ratio. If the P-value is less than 0.05 , it means there is a significant difference in the financial ratios between pre and post M\&A. In other case if the P-value is greater than 0.05 , there will be insignificant difference between the financial ratios for pre and post M\&A. The mean results are also discussed for each ratio.

Table 4: Mean of Averages from all Banks and P-Value for the Each Ratio

\begin{tabular}{llll}
\hline & Pre M\&A & Post M\&A & P-Value \\
\hline Profitability\& Efficiency & & & \\
Return on Equity (ROE) & 0.0991 & 0.7039 & 0.5248 \\
Return on Assets (ROA) & 0.0062 & -0.0120 & 0.1299 \\
Net Interest Margin & 0.0322 & 0.0341 & 0.6730 \\
Earnings Per Share (EPS) & 5.5456 & 3.7722 & $0.0202^{*}$ \\
Spread Ratio & 0.4649 & 0.3549 & $0.0161^{*}$ \\
Interest expense to Interest Income & 0.4791 & 0.6141 & $0.0129^{*}$ \\
Non Interest Income to Total Assets & 0.0143 & 0.0075 & 0.1116 \\
Non Interest Expense to total Income & 0.5308 & 0.4024 & 0.5975 \\
Liquidity & & & \\
Cash \& Cash equivalent to total assets & 0.1186 & 0.0975 & $0.0164^{*}$ \\
Investment to total assets & 0.1828 & 0.2926 & $0.0089^{*}$ \\
Advance net of provision to total assets & 0.4853 & 0.4519 & 0.4889 \\
Total Liabilities to total assets & 0.8640 & 0.9023 & 0.1017 \\
Leverage & & & \\
Debt to Equity Ratio & 9.1963 & 3.4556 & 0.5385 \\
Total Deposit to total Equity & 1.2663 & 1.4908 & 0.2465 \\
Capital Ratio & 0.1321 & 0.0898 & 0.0782 \\
\hline
\end{tabular}

Above table results show p-value and mean of each ratio. There is insignificant difference between pre and post M\&A to efficiency level at 5\% significant level for 10 out of 15 financial ratios of all banks' collectively. The null hypothesis is accepted for these ten ratios having P-value greater than 0.05. Other five ratios show significant difference between pre and post M\&A with the P-value is less than 0.05 , the null hypotheses are rejected for these five ratios. In profitability \& efficiency ratios, there are three ratios having significant difference out of eight ratio(s) between pre and post M\&A. These ratios involved EPS; spread ratio and interest expense to interest income. There is significant impact of M\&A on these ratios. The mean results showed that these ratios were significantly decreased in post M\&A period. Significance difference of EPS showed a negative improvement after M\&A, the results of EPS are according to the finding of Amel et al. (2004) and Muhammad (2010) found decrease in EPS after M\&A. However, the finding about EPS is not associated with the finding of (Lin et al., 2006 and Sinha \& Kaushik, 2010). The spread ratio showed a negative improvement after M\&A. Interest expense to interest income has also a 
negative improvement that means banks could not control interest expense, which is due to more debt financing after M\&A. The result of this ratio is associated with the findings of (Allah-Yar, 2012). Other five profitability ratios show insignificant difference between pre and post M\&A. It means there is no significant impact of M\&A on these ratios, but the mean results indicate that ROE is slightly improved in post M\&A period which is associated with the findings of (Ong et al., 2011). ROA is slightly decreased in Post M\&A period this result is supported by the findings of (All-Yar, 2012), they found insignificant difference for this ratio. Net interest margin is also slightly decreased in post period as per. Non-interest income shows insignificant difference but the mean value of post M\&A are decreased. Non-interest income to total asset is decreased in post M\&A period, which is positive improvement. Overall profitability of banks is decreased in the post M\&A period that means banks could not use their assets efficiently to generate more profit and they have not control on the costs of operations and other costs. Knapp et al. (2005) and Houstan et al. (2001) found that the profitability of banks improved after M\&A. However, Muhammad (2010) and Rhodes et al. (2004) did find decrease in profitability of banks after M\&A.

The liquidity ratios represent that there is significant difference in cash \& cash equivalent and investment to total asset ratio. The null hypotheses are rejected for these ratios. Cash and cash equivalent ratio is significantly decreased in post M\&A period but the investment to total asset ratio is significantly increased in post M\&A period. Allah-Yar (2012) found insignificant difference cash and cash equivalent ratio between pre and post M\&A. The other two liquidity ratios advance net of provision to total assets and total liabilities to total assets show insignificant difference between pre and post M\&A and the null hypotheses for these ratios are accepted. The mean value results of these ratios also indicate that there is no more increase or decrease in these ratios in post M\&A period. Overall, the liquidity of banks is not affected due to M\&A. Results of these ratios are in line with the findings of Allah-Yar (2012). The liquidity performance also found to be insignificant (Ong et al., 2011). The financial leverage of banks is represented by Debt to Equity Ratio, Total Deposit to total Equity and Capital Ratio. Above in Table 4 all these three ratios have insignificant difference between pre and post M\&A. It means there was no significant impact of M\&A on the financial leverage of banks. Debt to Equity ratio was positively improved, as shown by the mean value. There is negative effect on total deposit to total equity ratio according to the mean values. The capital ratio is decreased in post M\&A period. The operating losses are not protected of a firm having low capital ratio in post M\&A period. Overall, there is no more positive or negative effect of M\&A on the financial leverage of banks. The results of financial leverage are associated with findings of (Ong et al., 2011). They found insignificant relationship between pre and post Merger about the financial leverage of banks in Malaysia.

Paired sample t-Test Using SPSS: To indicate overall significant difference between the pre and post M\&A performance of the banks Paired sample t-Test is used where the mean of the averages is used for all ratios and the results are shown under in table 5.

Table 5: Paired Samples t-Test

\begin{tabular}{|c|c|c|c|c|c|c|c|c|}
\hline & \multicolumn{8}{|c|}{ Paired Differences } \\
\hline & Mean & $\begin{array}{l}\text { Std. } \\
\text { Deviation }\end{array}$ & $\begin{array}{l}\text { Std. Error } \\
\text { Mean }\end{array}$ & $\begin{array}{l}\text { 95\% Con } \\
\text { the Differ }\end{array}$ & $\begin{array}{l}\text { nce Interval of } \\
\mathrm{e}\end{array}$ & $\mathrm{T}$ & $\mathrm{DF}$ & Sig.(2-tailed) \\
\hline $\begin{array}{l}\text { Pair } \\
\text { PRE-POST }\end{array}$ & 0.4507 & 1.5477 & 0.39961 & $\begin{array}{l}\text { Lower } \\
-0.40641\end{array}$ & $\begin{array}{l}\text { Upper } \\
1.30774\end{array}$ & 1.128 & 14 & 0.278 \\
\hline
\end{tabular}

The results of the above table show insignificant difference between Pre and Post M\&A financial performance, because the P-value is greater than 0.05. So after the Merger and Acquisition there is no significant difference in the performance of banks in Pakistan and $\mathrm{H}_{0}$ is accepted. This result is similar with the findings of some previous researches like (Ong et al., 2011; Campa \& Hernando, 2006; Fauzias \& Rasidah, 2006 and Amel et al., 2004). They all found that there is insignificant difference in the financial performance of banking industries between pre and post M\&A. Even some ratios showed individually that there is slightly increase or decrease in the financial performance of banks, but it is examined now by this study that there is no significant impact. 
Discussions: Below in table 6 the findings of recent previous 25 studies are shown which were conducted in the same area of M\&A from the period of 2006-2012. Further detail of these studies is given in table 2 (Appendix 1)

Table 6: Comparison of the Results with the findings of 25 recent studies

\begin{tabular}{llllll}
\hline & Profitability & Efficiency & Liquidity & $\begin{array}{l}\text { Financial } \\
\text { Leverage }\end{array}$ & $\begin{array}{l}\text { Overall } \\
\text { Performance }\end{array}$ \\
\hline Increased & $62 \%$ & $50 \%$ & $10 \%$ & $0 \%$ & $48 \%$ \\
Decreased & $31 \%$ & $50 \%$ & $80 \%$ & $0 \%$ & $32 \%$ \\
$\begin{array}{l}\text { Average } \\
\text { Results/Insignificant }\end{array}$ & $8 \%$ & $0 \%$ & $10 \%$ & $100 \%$ & $20 \%$ \\
Total & $100 \%$ & $100 \%$ & $100 \%$ & $100 \%$ & $100 \%$ \\
Results of This study & Decrease & Decrease & Decrease & Decrease & Decrease \\
\hline
\end{tabular}

Source: Author's Compilation

This compilation indicates that out of 25 recent previous studies $62 \%$ studies finding shows increased, $31 \%$ decreased and $8 \%$ studies show average results in their profitability after M\&A. Similarly, the percentage in efficiency, leverage, liquidity, and financial performance is examined. However, as for the results of this study are concerned that all the financial performance indicators like; profitability, efficiency, liquidity, and leverage performance show decrease in post M\&A period. The results also indicate that the financial performance of banks slightly decreased in post M\&A period. State Bank of Pakistan indicates that during 2008-2010 the profitability of banks was improved as the liquidity was enhanced during 2003-2005. However, as per the results of this research the profitability of banks is decreased after M\&A, which is in lined during 2009-2011. It is the clear sign to the banks who want to go for M\&A transactions that under M\&A banks not performed well. The liquidity of banks is not improved after M\&A, but the liquidity of banks is declined (SBP, 2011). According to the financial statement analysis leverage ratios are examined as mixed trend but the results of the study provide negative improvement in the period of post M\&A according to the FSA by SBP, 2006-2011. Financial crises 2007 was the reason mentioned for the lowest improvement in the performance of banks in all over the world. Several products, which are available from banks to customers, have been standardized and changed after the M\&A. There are some disadvantages to the customers regarding customization services. Particularly this situation lied when the level of service is not well for customers during the period of M\&A. Therefore, the effect was in the reduction of their portfolio of assets and the income statement and balance sheet too.

\section{Conclusion}

Countless researches have been done throughout the world to determine the impact of this strategy on corporate sector. This study accomplished the declared gap in the area of M\&A in Pakistan. The purpose of this study is to assess the impact of M\&A on the financial performance of banks in Pakistan. Two statistical techniques are used in this study; first the analysis of pre and post M\&A financial ratios is drawn and second paired sample t-test is used. The results of the study show that there is insignificant difference in the financial performance of banks between pre and post M\&A. That means the performance of banks is not improved after the M\&A. There is decrease in profitability, efficiency, liquidity, and leverage ratio(s). The investment portion is enhanced by banks to some other businesses. Financial crises of 2007 was the one reason of less improvement in the financial performance. The other reason is liberalization and globalization where after the financial crises they tend to improve their banking system by hook or crook for which they have to extend borrowing to stable the industry. It is concluded that overall the activity M\&A did not perform well in banking sector of Pakistan. This research is an insight picture for all the financial and non-financial institutions those are going to use the approach M\&A, and the investors and stockholders should be familiar about performance of M\&A in the industry. It is recommended to regulatory body that they should review their policy and procedures. It is also recommended to SBP that they should evaluate the risks, which are involved in the financial performance, and they should make a proper framework for M\&A deals. CCP and SECP are recommended that there should be a proper mechanism for the assessment of M\&A deals. It is advised to the top-level management in the banks that they should evaluate latent opportunities to improve the financial performance before selecting and adopting for M\&A. The banks, which are not performing well after the M\&A they should minimize their operational costs and should improve the operation system too. This study has some limitations as it was conducted to measure the performance of banks which went for 
M\&A deals only on domestic level in Pakistan and here the performance of bidder banks only is measured. In Future the research may be conduct on cross border M\&A deals in all other sectors too adopting different other techniques to measure the financial indicators. The primary based research also may be conducted in Pakistan in the same area.

\section{References}

Achtmeyer, W. F. (1994). Strategic synergies: Fact or fiction? In Rock, m. L., Rock, R. H., Sikora, M. The Mergers and Acquisitions Handbook (2nd edition), 107-111.

Allah-Yar, K. (2012). Mergers \& Acquisitions: Pre and Post Analysis of the Financial Sector of Pakistan. Thesis on M\&A in the financial sector.

Amel, D., Barnes, C., Panetta, F. \& Salleo, C. (2004). Consolidation \& efficiency in the financial sector: A review of the international evidence. Journal of Banking \& Finance, 3, 2493- 2519.

Badreldin, A. \& Kalhoefer, C. (2009). The effect of mergers and acquisitions on bank performance in Egypt. Journal of Management Technology, 25, 1-15.

Berger, A. N., Demsetz, R. S. \& Strahan, P. F. (1999). The consolidation of the financial services industry: Causes, consequences, and implications for the future. Journal of Banking \& Finance, 23, 135-194.

Berger, A. N. \& DeYoung, R. (2001). The effects of geographic expansion on bank efficiency. J Finance Serv Res, 19, 163-184.

Berger, A. N. \& DeYoung, L. (1997). Problem loans and cost efficiency in commercial banks. Journal of Banking and Finance, 21, 849-870.

Calomiris, C. \& Karenski, J. (1996). The bank merger wave of the 1990s: Nine case studies: University of IIIinois.

Campa, J. M. \& Hernando, I. (2006). Merger and Acquisition Performance in the European financial industry. Journal of Banking \& Finance, 30, 3367-3392.

Caprion, L. (1999). The long term performance of horizontal acquisitions: INSEAD Work Paper, 99/24/SM, April.

Chapman, K. (2003). Cross-border mergers/acquisitions: A review and research agenda. Journal of Economic Geography, 3(3), 309-334.

Cornett, M. M., McNutt, J. J. \& Tehranian, H. (2006). Performance changes around bank mergers: Revenue enhancements versus cost reductions. Journal of Money, Credit and Banking, 38(4), 1013-1050.

Fauzias, M. N. \& Rasidah, M. (2006). Efficiency and financial performance changes of Malaysia Banking: Institutions in Merger and Acquisition, MFA 6th Annual Symposium.

Gjirja, M. (2001). Effects of deregulation and banking crisis on the labor use efficiency in the Swedish banking industry: Paper presented at the Seventh European Workshop on Efficiency and Productivity Analysis 7EWEPA, Oviedo, Spain.

Houstan, J. F., James, C. M. \& Ryngaert, M. D. (2001). Where Do Mergers Gains Come From? Bank Mergers from the Perspective of Insiders and Outsiders. Journal of Financial Economics, 60, 285-331.

Ismail, T. H., Abdou, A. A. \& Annis, R. M. (2011). Review of literature linking corporate performance to mergers and acquisitions: The Review of Financial and Accounting Studies, 1, 89-104.

IMAA. (2011). Announced Mergers \& Acquisitions: Worldwide, 1985-2010. Institute of Mergers, Acquisitions and Alliances. Industrial Organization, 12, 95-139.

Khan, A. A. (2011). Merger and Acquisitions in the Indian banking sector in post liberalization regime dept. of commerce. AMU, Aligarh India.

Knapp, M., Gart, A. \& David, B. (2005). Post-merger performance of bank holding companies, 1987-1998. The Financial Review, 40, 549-574.

Kouser, R. \& Saba, I. (2011). Effects Of business combination on financial performance: Evidence from Pakistan's banking sector. Australian Journal of Business and Management Research, 1(8), 54-64.

Kwan, S. H. \& Eisenbeis, R. B. (1999). Mergers of publicly traded banking organizations revisited. Economic Review, q4, 26-37.

Lin, B. W., Hung, S. C. \& Li, P. C. (2006). Mergers and acquisitions as a human resource strategy. International Journal of Manpower, 27(2), 126-142.

Mantravadi, P. \& Reddy, A. V. (2008). Post-merger performance of acquiring firms from different industries in India. International Research Journal of Finance and Economics, 22, 192-204.

Martynova, M., Oosting, S. \& Renneboog, L. (2006). The long-term operating performance of European mergers and acquisitions: Finance Working Paper, 137, November 2006, ECGI, 1-39.

Mishra, P. \& Chandra, T. (2010). Mergers, acquisitions and firms' performance: Experience of Indian pharmaceutical industry. Eurasian Journal of Business and Economics, 3(5), 111-126. 
Muhammad, U. K. (2010). Post-Merger Profitability: A Case of Royal Bank of Scotland (RBS). International Journal of Business and Social Science, 2(5).

Obaidullah, S. \& Usman, A. (2010). Post-merger performance of Atlas investment and Al-Faysal bank. International Research Journal of Finance and Economics, 3, 168-174.

Okpanachi, J. (2007). Global Syndromic Nature of Bank Distress: the Nigerian Perspective. Acad.J. Defense Stud., 14(1).

Ong, T. S., Teo, C. L. \& Teh, B. H. (2011). Analysis of financial performance and efficiency changes of Malaysian commercial banks after mergers and acquisitions. International Journal of Business and Management Tomorrow, 1(2).

Pankaj, S. \& Sushant, G. (2011). Mergers and Acquisitions: A pre-post analysis for the Indian financial services sector. Retrieved from: mpra.Ub.Un-Muenchen. De/31253/1/Mpra_Paper_31253.Pdf.

Ravichandran, K., Nor, F. M. \& Said, M. R. (2010). Market Based mergers in India banking institutions: International research. Journal of Finance and Economics, 37(2).

Rhodes-Kropf, M. \& Viswanathan, S. (2004). Market valuation and merger waves. The Journal of Finance, LIX (6).

SBP. (2011). Financial Sector Stability Review, Karachi: State Bank of Pakistan.

Sherman, A. J. (2011). Mergers \& Acquisitions: Retrieved from A to Z: AMACOM.

Sinha, P. \& Gupta, S. (2011). Mergers and Acquisitions: A Pre-Post Analysis for the Indian Financial Services Sector. Retrieved From mpra.Ub.Uni Muenchen, De/31253/1/Mpra_Paper_31253.

Sinha, N. \& Kaushik, K. P. (2010). Measuring post merger and Acquisition Performance: An Investigation of Select Financial Sector Organizations in India. International Journal of Economics and Finance, 2, 190-200.

Tambi, M. K. (2005). Impact of mergers \& amalgamation on the performance of Indian companies: Econ WPA Finance, 0506007.

Yener, A. \& David, M. I. (2004). Mergers and acquisitions and banks performance in Europe: The role of strategic similarities. Euro Central Bank Work Paper Series, 398.

Zahid, N. \& Shah, M. (2011). Merger and Acquisition in International Business. European Scientific Journal, 1, 43-56.

\section{APPENDIX 1}

Table 1: M\&A Deals in banking sector of Pakistan from the year 2002-2011

\begin{tabular}{|c|c|c|c|c|}
\hline S.N & $\begin{array}{l}\text { Type of } \\
\text { Deal }\end{array}$ & Date of Deal & Acquirer/Bidder Banks & Acquired/Merged/Target Banks \\
\hline 1 & Merger & $10 / 1 / 2002$ & Faysal Bank Limited & Al-Faysal Investment Bank \\
\hline 2 & Merger & $15 / 03 / 2002$ & Atlas Investment Bank Limited & Atlas Lease \\
\hline 3 & Merger & $22 / 07 / 2002$ & Trust Investment Bank Ltd. & Pakistan Industrial Leasing Corp. Ltd. \\
\hline 4 & Merger & $4 / 6 / 2003$ & KASB Bank Limited & KASB \& Company Limited \\
\hline 5 & Merger & $9 / 7 / 2003$ & Mashreq Bank Pakistan Limited & Crescent Investment Bank Limited \\
\hline 6 & Merger & $31 / 07 / 2003$ & First Standard Investment Bank Ltd. & First Cresecent Modaraba \\
\hline 7 & Merger & $17 / 10 / 2003$ & IFIC Bank Limited (Rs. 10 per share) & NDLC (Rs. 5 per share) \\
\hline 8 & Merger & $30 / 04 / 2004$ & Trust Commercial Bank Limited & Fidelity Investment Bank Limited \\
\hline 9 & Merger & $30 / 04 / 2004$ & Trust Commercial Bank Limited & Trust Investment Bank Limited \\
\hline 10 & Merger & $12 / 5 / 2004$ & $\begin{array}{l}\text { First Dawood Investment Bank } \\
\text { Limited }\end{array}$ & First General Leasing Modaraba \\
\hline 11 & Merger & $12 / 5 / 2004$ & $\begin{array}{l}\text { First Dawood Investment Bank } \\
\text { Limited }\end{array}$ & Industrial Capital Modaraba \\
\hline 12 & Merger & $18 / 06 / 2004$ & $\begin{array}{l}\text { First Standard Investment Bank } \\
\text { Limited }\end{array}$ & First Leasing Corporation Limited \\
\hline
\end{tabular}




\begin{tabular}{|c|c|c|c|c|c|}
\hline 13 & Merger & $18 / 06 / 2004$ & $\begin{array}{l}\text { First Standard Investment } \\
\text { Limited }\end{array}$ & Bank & Paramount Leasing Limited \\
\hline 14 & Merger & $18 / 06 / 2004$ & $\begin{array}{l}\text { First Standard Investment } \\
\text { Limited }\end{array}$ & Bank & Pacific Leasing Company Limited \\
\hline 15 & Merger & $18 / 10 / 2004$ & \multicolumn{2}{|l|}{ Crescent Commercial Bank Limited } & Trust Commercial Bank Limited \\
\hline 16 & Merger & $31 / 05 / 2005$ & \multicolumn{2}{|l|}{ Allied Bank Limited } & Ibrahim Leasing Limited \\
\hline 17 & Merger & $26 / 07 / 2006$ & \multicolumn{2}{|l|}{ Atlas Bank Limited } & Atlas Investment Bank Limited \\
\hline 18 & Merger & $25 / 08 / 2006$ & \multicolumn{2}{|l|}{ Allied Bank Limited } & First Allied Bank Modaraba \\
\hline 19 & Merger & $29 / 12 / 2006$ & \multicolumn{2}{|l|}{ Standard Chartered Bank Ltd. } & Union Bank Limited \\
\hline 20 & Merger & $30 / 12 / 2006$ & \multicolumn{2}{|l|}{ JS Bank Limited } & Jahangir Siddiqui Inv. Bank Ltd. \\
\hline 21 & Merger & $20 / 07 / 2007$ & \multicolumn{2}{|c|}{ Innovative Housing Finance Limited } & Crescent Standard Investment Bank Ltd. \\
\hline 22 & Merger & $22 / 11 / 2007$ & \multicolumn{2}{|l|}{ KASB Bank Limited } & International Housing Finance Ltd. \\
\hline 23 & Merger & $31 / 12 / 2007$ & \multicolumn{2}{|l|}{ NIB Bank Limited. } & Pakistan Credit and Investment Corporation \\
\hline 24 & Merger & $31 / 12 / 2007$ & \multicolumn{2}{|l|}{ NIB Bank Limited. } & PICIC Commercial Bank Limited \\
\hline 25 & Acquisition & $31 / 12 / 2007$ & \multicolumn{2}{|l|}{ NIB Bank Limited } & Global Securities Pakistan Limited \\
\hline 26 & Merger & $1 / 1 / 2008$ & \multicolumn{2}{|l|}{ NIB Bank Limited } & $\begin{array}{l}\text { Pakistan Industrial Credit \& Investment } \\
\text { Corp. Ltd }\end{array}$ \\
\hline 27 & Merger & $1 / 1 / 2008$ & \multicolumn{2}{|l|}{ NIB Bank Limited } & PICIC Commercial Bank Limited \\
\hline 28 & Acquisition & $20 / 05 / 2008$ & \multicolumn{2}{|l|}{ Malayan Banking Berhad } & MCB Bank Limited by M/s \\
\hline 29 & Acquisition & $22 / 05 / 2008$ & \multicolumn{2}{|c|}{$\begin{array}{l}\text { The Royal Bank of Scotland Group } \\
\text { PLC. }\end{array}$} & ABN Amro Bank ( Pakistan ) Limited \\
\hline 30 & Acquisition & $25 / 06 / 2008$ & \multicolumn{2}{|l|}{ Standard Chartered Bank Limited. } & American Express Bank Limited in Pakistan. \\
\hline 31 & Acquisition & $15 / 09 / 2008$ & \multicolumn{2}{|l|}{ Habib Bank Limited. } & Saif Power Limited \\
\hline 32 & Acquisition & $28 / 10 / 2008$ & \multicolumn{2}{|l|}{ Dubai Banking Group LLC. } & BankIslami Pakistan Limited \\
\hline 33 & Acquisition & $31 / 10 / 2008$ & \multicolumn{2}{|l|}{ Unicornn Investment Bank. } & Sweetwater Dairies Pakistan (Pvt) Limited \\
\hline 34 & Merger & $7 / 11 / 2008$ & \multicolumn{2}{|l|}{ Atlas Bank Limited } & $\begin{array}{l}\text { Merger of KASB Bank Limited, KASB Capital } \\
\text { and }\end{array}$ \\
\hline 35 & Merger & $5 / 12 / 2008$ & \multicolumn{2}{|l|}{ KASB Bank Limited. } & Network Leasing Corporation Limited \\
\hline 36 & Acquisition & $29 / 01 / 2009$ & \multicolumn{3}{|c|}{ Bahrain. } \\
\hline 37 & Merger & $30 / 01 / 2009$ & \multicolumn{2}{|l|}{ HSBC Bank Middle East Limited. } & $\begin{array}{l}\text { Amalgamation of the Hong Kong and } \\
\text { Shanghai Banking Corporation (all branches } \\
\text { in Pakistan ) }\end{array}$ \\
\hline 38 & Acquisition & $27 / 03 / 2009$ & \multicolumn{2}{|l|}{ Bank Al Haibib Limited. } & Habib Sugar Mills Limited \\
\hline 39 & Merger & $9 / 7 / 2009$ & $\begin{array}{l}\text { Invest Capital Investment } \\
\text { Limited. }\end{array}$ & Bank & $\begin{array}{l}\text { Al-Zamin Leasing Modaraba and Al-Zamin } \\
\text { Leasing Corporation Limited }\end{array}$ \\
\hline 40 & Acquisition & $31 / 08 / 2009$ & MCB Bank Limited & & Royal Bank of Scotland \\
\hline 41 & Merger & $22 / 12 / 2009$ & Askari Bank Limited & & Askari Leasing Limited \\
\hline 42 & Merger & $11 / 1 / 2010$ & $\begin{array}{l}\text { Invest Capital Investment } \\
\text { Limited }\end{array}$ & Bank & Al-Zamin Leasing Corporation Limited \\
\hline
\end{tabular}




\begin{tabular}{|c|c|c|c|c|}
\hline 43 & Merger & $11 / 1 / 2010$ & $\begin{array}{l}\text { Invest Capital Investment Bank } \\
\text { Limited }\end{array}$ & Al-Zamin Leasing Modaraba \\
\hline 44 & Acquisition & $9 / 2 / 2010$ & National Bank of Pakistan. & $\begin{array}{l}\text { National Fullerton Asset Management } \\
\text { Limited }\end{array}$ \\
\hline 45 & Merger & $10 / 3 / 2010$ & Askari Bank Limited & Askari Leasing Limited \\
\hline 46 & Acquisition & $10 / 8 / 2010$ & Faysal Bank Limited. & The Royal Bank of Scotland Limited \\
\hline 47 & Acquisition & $19 / 10 / 2010$ & . Bank Al Falah Limited. & National Bank of Pakistan \\
\hline 48 & Acquisition & $19 / 10 / 2010$ & Meezan Bank Limited. & Haleeb Foods Limited \\
\hline 49 & Acquisition & $20 / 10 / 2010$ & Bank Al Falah Limited. & KASB Securities Limited \\
\hline 50 & Merger & $28 / 10 / 2010$ & Emirates global Islamic Bank Limited & Merger of Al Baraka Islamic Bank \\
\hline 51 & Acquisition & $24 / 12 / 2010$ & Bank Islami Pakistan Limited. & Citibank Housing Finance Business portfolio \\
\hline 52 & Merger & $3 / 1 / 2011$ & Faysal Bank Limited & The Royal Bank of Scotland Limited \\
\hline 53 & Merger & $11 / 1 / 2011$ & Summit Bank Limited & Atlas Bank Limited \\
\hline 54 & Acquisition & $2 / 6 / 2011$ & Habib Bank Limited. & $\begin{array}{l}\text { New Jubilee Life Insurance Company } \\
\text { Limited }\end{array}$ \\
\hline 55 & Acquisition & $2 / 6 / 2011$ & Habib Bank Limited. & New Jubilee Insurance Company \\
\hline 56 & Merger & $6 / 7 / 2011$ & Summit Bank Limited & My Bank Limited \\
\hline 57 & Acquisition & $3 / 11 / 2011$ & JS Bank Limited. & JS Global Capital Limited. \\
\hline
\end{tabular}

Table 2: Author's compilation about recent 25 Studies in the area of M\&A

\begin{tabular}{|c|c|c|c|c|c|c|c|}
\hline \multirow[t]{2}{*}{ Author } & \multirow{2}{*}{$\begin{array}{l}\text { Year of } \\
\text { Study }\end{array}$} & \multirow[t]{2}{*}{ Title Of study } & \multicolumn{5}{|l|}{ Findings } \\
\hline & & & Profitability & Efficiency & Liquidity & $\begin{array}{l}\text { Financial } \\
\text { Leverage }\end{array}$ & $\begin{array}{l}\text { Overall } \\
\text { Financial } \\
\text { Performance }\end{array}$ \\
\hline Cornett et al. & 2006 & $\begin{array}{l}\text { Performance } \\
\text { changes around } \\
\text { bank mergers: } \\
\text { Revenue } \\
\text { enhancements } \\
\text { versus cost } \\
\text { reductions }\end{array}$ & & Decrease & & & Increase \\
\hline Lin et al. & 2006 & $\begin{array}{l}\text { Benefits from a } \\
\text { changing payment } \\
\text { technology in } \\
\text { European banking } \\
\text { under M\&A }\end{array}$ & Increase & & & & Increase \\
\hline Campa et al & 2006 & $\begin{array}{l}\text { M \& As } \\
\text { Performance in the } \\
\text { European financial } \\
\text { industry }\end{array}$ & & & & & Average \\
\hline Lin et al. & 2006 & $\begin{array}{l}\text { Mergers and } \\
\text { Acquisitions As A } \\
\text { Human Resource } \\
\text { Strategy }\end{array}$ & & & & & Increase \\
\hline $\begin{array}{l}\text { Campa and } \\
\text { Hernando }\end{array}$ & 2006 & $\begin{array}{l}\text { M \& As } \\
\text { Performance in the } \\
\text { European financial } \\
\text { industry }\end{array}$ & & Increase & & & Increase \\
\hline Ayadi & 2007 & & & & Decrease & & Average \\
\hline $\begin{array}{l}\text { Tuch\& } \\
\text { Sullivan }\end{array}$ & 2007 & $\begin{array}{l}\text { impact of } \\
\text { Acquisitions on } \\
\text { Firm Performance }\end{array}$ & & & & & Decrease \\
\hline
\end{tabular}




\begin{tabular}{|c|c|c|c|c|c|c|c|}
\hline $\begin{array}{l}\text { Mantravadi \& } \\
\text { Reddy }\end{array}$ & 2008 & $\begin{array}{l}\text { Post-merger } \\
\text { performance of } \\
\text { acquiring firms } \\
\text { from different } \\
\text { industries in India }\end{array}$ & & & & & Decrease \\
\hline $\begin{array}{l}\text { Badreldin and } \\
\text { Kalhoefer }\end{array}$ & 2009 & $\begin{array}{l}\text { The effect of } \\
\text { mergers and } \\
\text { acquisitions on } \\
\text { bank performance } \\
\text { in Egypt }\end{array}$ & Increase & & & & Increase \\
\hline Kumar & 2009 & $\begin{array}{lr}\text { The impact } & \text { of } \\
\text { mergers } & \text { and } \\
\text { acquisitions } & \text { on } \\
\text { corporate } & \\
\text { performance } & \text { in } \\
\text { India } & \end{array}$ & Decrease & & Decrease & & Decrease \\
\hline Ismail & 2010 & $\begin{array}{lr}\text { Review } & \text { of } \\
\text { literature linking } \\
\text { corporate } \\
\text { performance } \\
\text { mergers } \\
\text { acquisitions }\end{array}$ & Decrease & & Decrease & & Decrease \\
\hline Braggion et al. & 2010 & $\begin{array}{l}\text { Mergers and } \\
\text { Acquisitions in } \\
\text { British Banking: } \\
\text { Forty Years of } \\
\text { Evidence from } \\
1885 \text { until } 1925\end{array}$ & & & Decrease & & Average \\
\hline Usman et al & 2010 & $\begin{array}{l}\text { Post-Merger } \\
\text { Profitability: A } \\
\text { Case of Royal Bank } \\
\text { of Scotland (RBS) }\end{array}$ & Decrease & & & & Decrease \\
\hline $\begin{array}{l}\text { Sinha } \quad \& \\
\text { Kaushik }\end{array}$ & 2010 & $\begin{array}{l}\text { Mergers and } \\
\text { Acquisitions: A } \\
\text { Pre-Post Analysis } \\
\text { for the Indian } \\
\text { Financial Services } \\
\text { Sector }\end{array}$ & & & & & Increase \\
\hline $\begin{array}{l}\text { Obaidullah et } \\
\text { al. }\end{array}$ & 2010 & $\begin{array}{l}\text { Post-merger } \\
\text { performance of } \\
\text { Atlas investment } \\
\text { and Al-Faysal }\end{array}$ & increase & & & & Increase \\
\hline Muhammad & 2010 & $\begin{array}{l}\text { Post-Merger } \\
\text { Profitability of } \\
\text { Banks }\end{array}$ & Decrease & & & & Decrease \\
\hline Braggion et al & 2010 & $\begin{array}{lr}\text { Mergers } & \text { and } \\
\text { Acquisitions } & \text { in } \\
\text { British Banking } & \end{array}$ & & & Decrease & & Decrease \\
\hline $\begin{array}{l}\text { Sinha } \\
\text { Gupta }\end{array}$ & 2011 & $\begin{array}{l}\text { Mergers and } \\
\text { Acquisitions: A } \\
\text { Pre-Post Analysis }\end{array}$ & Increase & & & & Increase \\
\hline Ong et al. & 2011 & $\begin{array}{l}\text { Analysis on } \\
\text { financial } \\
\text { performance and } \\
\text { efficiency changes } \\
\text { of Malaysian } \\
\text { commercial banks } \\
\text { after mergers and } \\
\text { acquisitions }\end{array}$ & Increase & Increase & & Average & Increase \\
\hline Houstan et al. & 2011 & $\begin{array}{l}\text { Where Do Mergers } \\
\text { Gains Come From? } \\
\text { Bank Mergers } \\
\text { From } \\
\text { Perspective The }\end{array}$ & Increase & & & & Increase \\
\hline
\end{tabular}




\begin{tabular}{|c|c|c|c|c|c|c|c|}
\hline & & $\begin{array}{ll}\text { Insider } & \text { And } \\
\text { Outsiders } & \end{array}$ & & & & & \\
\hline Khan et al. & 2011 & $\begin{array}{l}\text { Effect of Mergers } \\
\text { and Acquisitions } \\
\text { on Market } \\
\text { Concentration and } \\
\text { Interest Spread }\end{array}$ & & Decrease & Increase & & Average \\
\hline \multirow[t]{3}{*}{ Sinha Kaushik } & 2011 & $\begin{array}{lr}\text { Measuring } & \text { Post } \\
\text { Merger } & \text { and } \\
\text { Acquisition } & \\
\text { Performance: } & \text { An } \\
\text { Investigation } & \text { of }\end{array}$ & Increase & & Decrease & & Increase \\
\hline & & $\begin{array}{l}\text { Select } \quad \text { Financial } \\
\text { Sector }\end{array}$ & & & & & \\
\hline & & $\begin{array}{l}\text { Organizations in } \\
\text { India }\end{array}$ & & & & & \\
\hline Kemal. & 2011 & $\begin{array}{lr}\text { Assessing } & \text { the } \\
\text { performance } & \text { of } \\
\text { banking M\&A in } \\
\text { Europe }\end{array}$ & Average & & Average & Average & Average \\
\hline $\begin{array}{l}\text { Pankaj and } \\
\text { Sushant. }\end{array}$ & 2011 & $\begin{array}{lr}\text { Mergers } & \text { and } \\
\text { Acquisitions: } & \mathrm{A}\end{array}$ & increase & & Decrease & & Increase \\
\hline & & $\begin{array}{l}\text { Pre-Post } \text { Analysis } \\
\text { for the Indian } \\
\text { Financial Services } \\
\text { Sector }\end{array}$ & & & & & \\
\hline Allah-Yar & 2012 & $\begin{array}{l}\text { Mergers \& } \\
\text { Acquisitions: Pre } \\
\text { and Post Analysis } \\
\text { of the Financial } \\
\text { Sector of Pakistan }\end{array}$ & & Decrease & Decrease & & Decrease \\
\hline
\end{tabular}

